\title{
Photocatalytic Decomposition of Air Pollutants Using Electrodeposited Photocatalysts on Stainless Steel
}

\author{
Andreas Hänel ${ }^{1 *}$, Marcin Janczarek ${ }^{1,2}$, Marek Lieder ${ }^{1}$, Jan Hupka ${ }^{1}$ \\ ${ }^{1}$ Department of Chemical Technology, Faculty of Chemistry, Gdansk University of Technology, Gdansk, Poland \\ ${ }^{2}$ Hokkaido University, Institute for Catalysis, Sapporo, Japan
}

Received: 20 August 2017

Accepted: 23 December 2017

\begin{abstract}
The aim of our research was to develop an immobilization method for photocatalysts that is an alternative to the sol-gel or dip-coating methods and can be simply scaled up for technical applications. The investigated photocatalyst was $\mathrm{TiO}_{2}$, which was electrochemically deposited onto a cathode made of stainless steel. This deposited film was photocatalytically active. In order to enhance the photoactivity of the $\mathrm{TiO}_{2}$ film, commercially available $\mathrm{P} 25$ photocatalyst nanoparticles were occluded into the film. The effect of deposition current density as well as the amount of occluded nanoparticles on the photocatalytic activity and photoelectrochemical behavior was investigated. The photocatalytic activity was evaluated in a UV-LED reactor. The decomposition rate of toluene and cyclohexane in air was examined for all prepared stainless steel-photocatalyst composites. It was observed that deposits prepared with $5 \mathrm{~g} \mathrm{dm}^{-3}$ of P25 in the deposition bath showed the best photocatalytic activity and highest photocurrent.
\end{abstract}

Keywords: cathodic deposition, titanium dioxide, nanoparticle occlusion, immobilization, heterogeneous photocatalysis

\section{Introduction}

Although fundamentals of photocatalyst functioning have been studied for several decades, the technical or large-scale application is a long time coming. In laboratory scale, dispersed photocatalysts are preferentially applied due to better photocatalytic activity, which results from the large surface area of particles. The recycling and reuse of the photocatalyst would be an essential step in technical applications.

*e-mail: andhaene@pg.edu.pl
Thus, the immobilization of photocatalysts onto a support material would be convenient. However, the immobilization of the photocatalysts has not yet been satisfactorily achieved [1-4]. In the ideal case, the support material and matrix for immobilization should feature the following properties [5]: 1) Strong anchoring of the photocatalyst preventing detachment, 2) Promoting the activity of the photocatalyst (e.g., offering large surface area, preventing recombination, or transmitting irradiation), and 3) Being chemically stable during photocatalytic reactions.

Photocatalysts can be synthesized by gas phase hydrolysis, chemical vapor deposition, sputtering, 
electrochemical, direct oxidation of transition metals, micro-emulsion, sol-gel, or the hydrothermal method [3, 6]. Two electrochemical methods can be distinguished: anodic oxidation of metal sheets and cathodic deposition. Anodic oxidation and growth of ordered structures has been well known for decades, especially for aluminum [7]. However, the work of Zwilling et al. [8] in 1999 initiated research on $\mathrm{TiO}_{2}$ nanotube formation by anodization, which advanced the development of third-generation titanium nanotube synthesis in nearly water-free electrolytes $[9,10]$. In contrast, during the cathodic procedure the photocatalyst can be deposited on different kinds of conductive material. Cathodic $\mathrm{TiO}_{2}$ deposition is applied for the preparation of capacitors [11], cathodic protection layers [12], photonic crystals, batteries, or dye-sensitized solar cells [13-16]. Two cathodic deposition methods can be distinguished: electrosynthesis and electrophoretic deposition. Pifferi et al. [17] prepared $\mathrm{TiO}_{2}$ films by electrophoretic method for photocatalytic $\mathrm{Cr}(\mathrm{VI})$ reduction. They obtained the best performance using Hombikat UV100 photocatalyst particles. Nevertheless, in comparison to all previously mentioned methods of photocatalyst preparation, only little information can be found in the literature about the photocatalytic activity of cathodically synthesized $\mathrm{TiO}_{2}$ [16]. Chenthamarakshan et al. [18] determined the photocatalytic reduction of $80 \mu \mathrm{M} \quad \mathrm{Cr}(\mathrm{VI})$ using a xenon arc lamp. The photocatalysts were potentiostatically deposited on conductive glass at $-1.2 \mathrm{~V}$ for up to $20 \mathrm{~min}$. Samples that were annealed at $400^{\circ} \mathrm{C}$ showed a larger photocatalytic reduction rate $\left(12.6 \mu \mathrm{M} \mathrm{min}^{-1}\right)$ when compared to samples annealed at $550^{\circ} \mathrm{C}\left(10.2 \mu \mathrm{M}\right.$ min $\left.^{-1}\right)$, assuming zero-order kinetics. Georgieva [19] investigated methanol photooxidation under UV and visible light irradiation using a Nafion-based photoelectrochemical cell with cathodically deposited $\mathrm{TiO}_{2} / \mathrm{WO}_{3}$ photoanodes. In another study Georgieva et al. [20] investigated the photoelectrolytic degradation of 4-chlorophenol, where the optimal atomic ratio was found to be Ti:W $=1.0-1.2$. Ishizaki and Ito [21] have electrochemically grown $\mathrm{TiO}_{2}$ films from titanium potassium oxalate dehydrate aqueous solution containing hydroxylamine. They observed the highest photocatalytic activity for acetaldehyde decomposition of films deposited at $-1.3 \mathrm{~V}$ vs $\mathrm{Ag} / \mathrm{AgCl}$ reference electrode. Sayahi et al. [22] electrodeposited $\mathrm{TiO}_{2}$ from a sacrificial anode on stainless steel using acetone with less than $1 \%$ water as electrolyte. Films deposited at $15 \mathrm{~V}$ showed the highest photocatalytic decomposition rate of methylene blue and exhibited good mechanical stability.

The aim of the present paper was to investigate cathodic deposition of $\mathrm{TiO}_{2}$ films as an alternative immobilization method and to determine the photoactivity of the deposits in dependence on cathodic deposition parameters. The photoactivity was determined by decomposition of cyclohexane and toluene in the gas phase and by the measurement of photocurrent. The advantages of cathodic deposition methods are that the film thickness can be controlled by adjusting the current density or cell potential over time and that films can be deposited on inexpensive conductive materials. If water-soluble titanium complexes are used as a precursor, control over the reaction conditions is easier, and higher precursor concentrations can be applied than in comparison to methods using titanium alkoxides $[23,24]$. The last three points are especially important for technical applications. Furthermore, the activity of cathodically deposited $\mathrm{TiO}_{2}$ films can be modified and enhanced by the occlusion of external photocatalyst particles (e.g., prepared by sol-gel, microemulsion, or the hydrothermal method).

\section{Experimental}

\section{Material and Methods}

All reagents were used as received without further purification. Titanium(IV) oxysulfate was purchased from Alfa Aesar, potassium nitrate (99\%, pure p.a.) was obtained from POCh Gliwice (Poland), hydrogen peroxide (30\%) was received from P.P.H. Stanlab Sp. J., and nitric acid (65\%) was obtained from Chempur. The used working electrode $(3.2 \times 3.6 \mathrm{~cm})$ was a stainless steel mesh (SS) AISI 304 (24 mesh per inch, wire diameter 0.014"'). For all electrochemical experiments, platinum mesh was used as a counter electrode and the $\mathrm{Ag} / \mathrm{AgCl}$ ( $\mathrm{KCl}$ sat.) electrode was used as reference electrode, whereas all mentioned potentials were measured with respect to this reference electrode. All electrochemical experiments were carried out with the Electrochemical Unit ATLAS 0531 from Atlas-Sollich.

\section{Cathodic Deposition}

The cathodic deposition method is based on the hydrolysis of titanium peroxo complexes by $\mathrm{OH}^{-}$ions, which leads to the formation of a peroxotitanium hydrate directly on the electrode [24-26]:

$$
\begin{gathered}
{\left[\mathrm{Ti}\left(\mathrm{O}_{2}\right)(\mathrm{OH})_{n-2}\right]^{(4-n)+}+m \mathrm{OH}^{-}+k \mathrm{H}_{2} \mathrm{O}} \\
\rightarrow \mathrm{TiO}_{3}\left(\mathrm{H}_{2} \mathrm{O}\right)_{x}
\end{gathered}
$$

$\mathrm{OH}^{-}$ions can be generated by the following reactions $[27,28]$ :

$$
\begin{gathered}
2 \mathrm{H}_{2} \mathrm{O}+2 \mathrm{e}^{-} \leftrightarrow \mathrm{H}_{2} \uparrow+2 \mathrm{OH}^{-} \\
\mathrm{E}^{\circ}=-0.828 \mathrm{~V} \\
\mathrm{NO}_{3}^{-}+\mathrm{H}_{2} \mathrm{O}+2 \mathrm{e}^{-} \leftrightarrow \mathrm{NO}_{2}^{-}+2 \mathrm{OH}^{-} \\
\mathrm{E}^{\circ}=0.01 \mathrm{~V} \\
\mathrm{NO}_{3}^{-}+7 \mathrm{H}_{2} \mathrm{O}+8 \mathrm{e}^{-} \leftrightarrow \mathrm{NH}_{4}^{+}+10 \mathrm{OH}^{-} \\
\mathrm{E}^{\circ}=-0.12 \mathrm{~V}
\end{gathered}
$$




$$
\begin{gathered}
\mathrm{O}_{2}+2 \mathrm{H}_{2} \mathrm{O}+4 \mathrm{e}^{-} \leftrightarrow 4 \mathrm{OH}^{-} \\
\mathrm{E}^{\circ}=0.401 \mathrm{~V}
\end{gathered}
$$

Subsequently, the peroxotitanium hydrate is decomposed by heat treatment, which leads to the formation of $\mathrm{TiO}_{2}$ :

$$
2 \mathrm{TiO}_{3}\left(\mathrm{H}_{2} \mathrm{O}\right)_{x} \rightarrow 2 \mathrm{TiO}_{2}+\mathrm{O}_{2}+2 x \mathrm{H}_{2} \mathrm{O}
$$

The photocatalysts were galvanostatically deposited at 5,10 , and $15 \mathrm{~mA} \mathrm{~cm}^{-2}$. The deposition bath consisted of $0.02 \mathrm{M} \mathrm{TiOSO}_{4}, 0.03 \mathrm{M} \mathrm{H}_{2} \mathrm{O}_{2}, 0.05 \mathrm{M} \mathrm{HNO}_{3}$, and $0.1 \mathrm{M} \mathrm{KNO}_{3}$ [20]. The deposition time was fixed at 60 min. The occlusion of Aeroxide $\mathrm{TiO}_{2}$ P25 was achieved by suspending $0.5,1.0$, and $5.0 \mathrm{~g} \mathrm{dm}^{-3}$ of photocatalyst powder in the deposition bath. The current density was set at $15 \mathrm{~mA} \mathrm{~cm}^{-2}$ for $60 \mathrm{~min}$ and the bath was stirred every $5 \mathrm{~min}$ to prevent precipitation. The $\mathrm{pH}$ was around 1.4 before the deposition experiments. In preliminary experiments, nickel, graphite, and stainless steel were evaluated as working electrode materials [29]. Nickel reacted with the deposition bath solution and graphite biased the measurement of photocatalytic activity by adsorping the model compounds. Stainless steel was chosen for further experiments, since it did not adversely affect the deposition or photocatalytic activity measurement. Furthermore, stainless steel is a commonly used construction material, which can be additionally functionalized by the deposition of a photoactive film. The stainless steel electrodes were rinsed with water, acetone, and methanol, and were etched in diluted $\mathrm{HCl}$ to remove a layer of oxides. When the photocatalysts had been deposited onto the stainless steel electrode, the samples were subsequently rinsed with deionized water, dried at $100^{\circ} \mathrm{C}$ for $1 \mathrm{~h}$, and annealed at $450^{\circ} \mathrm{C}$ for $1 \mathrm{~h}$.

\section{Characterization of the Deposited Films}

The photocatalytic activity of the electrochemically deposited photocatalysts was determined according to the procedure described earlier $[30,31]$. Two model compounds (150 ppm cyclohexane and $100 \mathrm{ppm}$ toluene) were decomposed in air. The experiments were repeated at least three times. The photoreactor has a volume of $34 \mathrm{ml}$ and was irradiated by a set of UV-LEDs (total $364 \mathrm{~mW}, \lambda=375 \mathrm{~nm}$ ). The UV radiant flux density

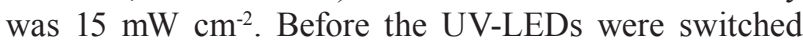
on, the sample in the reactor was kept in the dark for $30 \mathrm{~min}$, achieving the equilibrium of adsorption. The experiments were carried out at room temperature. Gas aliquots of $200 \mu \mathrm{l}$ were taken and the concentration was determined by gas chromatography. The gas chromatograph Clarus 500, PerkinElmer was equipped with a flame ionization detector and Elite-5 capillary column (30 m x $0.25 \mathrm{~mm}, 0.25 \mu \mathrm{m})$.

The photoelectrochemical characterization was done by irradiation with a $105 \mathrm{~W}$ black light bulb
(UV-flux $3.5 \mathrm{~mW} \mathrm{~cm}^{-2}$ ). The potential was cycled between 0 to $0.8 \mathrm{~V}$ at a sweeping rate of $10 \mathrm{mV} \mathrm{s}{ }^{-1}$. The samples were cycled twice in the dark and under UV irradiation in order to achieve a near-steady state response for the second cycle [20]. The supporting electrolyte was $0.1 \mathrm{M} \mathrm{Na}_{2} \mathrm{SO}_{4}$.

For scanning electron microscopy (SEM), Leo $1430 \mathrm{VP}$ was used, which was equipped with an energydispersive X-ray spectrometer (EDX) Quantax 200 and XFlash 4010 detector from Buker AXS, Germany. XPS analysis was conducted using JPC-9010MC from the JEOL Company. XRD patterns were determined by Rigaku MiniFlex $600(40 \mathrm{kV}, 15 \mathrm{~mA})$. When required (like for XPS but also for XRD characterization), the deposited films were scratched off the stainless steel electrode with a quartz scraper.

The electrode area, which was covered by photocatalyst, was determined by cyclic voltammetry using the Randles-Sevcik Equation. The analyte (5 $\mathrm{mM} \mathrm{K}_{3}\left[\mathrm{Fe}(\mathrm{CN})_{6}\right]$ in $1 \mathrm{M} \mathrm{KNO}_{3}$ ) was purged with nitrogen in an atmospheric sealed electrochemical cell. The dimensions of the working electrode were $1.9 \times 2.4 \mathrm{~cm}$ in order to fit into the electrochemical cell. All experiments were carried out at room temperature. The potential was swept between $0.6 \mathrm{~V}$ to $-0.75 \mathrm{~V}$ at sweep rates of $200,150,100,75$, and $50 \mathrm{mV} \mathrm{s}^{-1}$.

\section{Results and Discussion}

The deposition of photocatalyst film on stainless steel was examined under SEM (Fig. 1). The film was cracked and flaky without pores, which was similar to the findings of Chigane and Shinagawa [14]. The deposited film cracked during drying and annealing due to shrinking processes. After the addition of P25 particles to the deposition bath, the particles attached only to the cathodically formed $\mathrm{TiO}_{2}$ film (Fig. 2). The attached particles had diameters of up to $600 \mathrm{~nm}$, whereas spherical $\mathrm{TiO}_{2}$ film caps had diameters of around $2.5 \mu \mathrm{m}$. This can be explained by the fact that

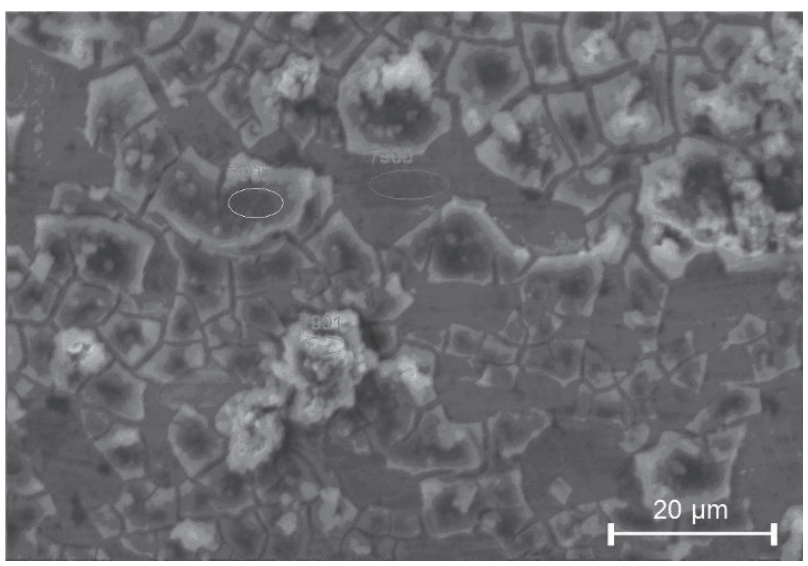

Fig. 1. SEM image of the galvanostatically deposited $\mathrm{TiO}_{2}$ at $15 \mathrm{~mA} \mathrm{~cm}^{-2}$ onto stainless steel. 


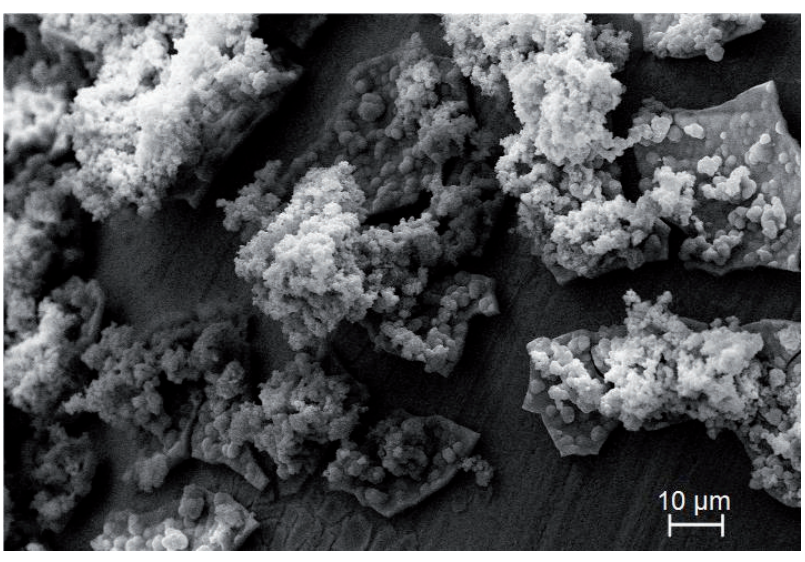

Fig. 2. SEM image of immobilized P25 particles onto the cathodically formed $\mathrm{TiO}_{2}$ film from deposition bath which contained $0.5 \mathrm{~g} \mathrm{dm}-3 \mathrm{P} 25$.

peroxotitanium hydrate was formed in the vicinity of the electrode and immediately precipitated.

The impact of current density and the amount of P25 particles in the deposition bath on the amount of deposited film is shown in Table 1. With increasing current density or with increasing amount of P25 in the bath, the amount of deposited photocatalyst increased.

The coverage of stainless steel by $\mathrm{TiO}_{2}$ was $35.4 \% \pm 0.7,45.6 \% \pm 0.9$, and $54.8 \% \pm 1.4$ for deposition at 15,10 , and $5 \mathrm{~mA} \mathrm{~cm}{ }^{-2}$, respectively. The amount of deposited $\mathrm{TiO}_{2}$ per electrode area was indirectly proportional to the covering of the electrode area due to strains in the film with increasing film thickness. During drying and annealing, the film was cracking and the gaps widened. SEM images revealed that with higher amounts of deposited $\mathrm{TiO}_{2}$ the photocatalyst film flakes were bending upwards, which in turn diminished the measured coverage.

Two samples were analyzed by XPS: one sample before annealing and the second one after annealing at $450^{\circ} \mathrm{C}$. The correction of binding energies was done according to the $\mathrm{C} 1 \mathrm{~s}$ peak at $284.8 \mathrm{eV}$. The XPS spectra shown in Fig. 3 displays Ti 2 p peak, which splits into

Table 1. Dependency of current density and P25 amount in deposition bath on photocatalyst mass per area of samples for cleaning air from model compounds.

\begin{tabular}{|c|c|c|}
\hline $\begin{array}{c}\text { Current density } \\
\left(\mathrm{mA} \mathrm{cm}^{-2}\right)\end{array}$ & $\begin{array}{c}\text { P25 amount } \\
\text { in the bath } \\
\left(\mathrm{g} \mathrm{dm}^{-3}\right)\end{array}$ & $\begin{array}{c}\text { Mass/Electrode } \\
\text { area } \\
\left(\mathrm{mg} \mathrm{cm}^{-2}\right)\end{array}$ \\
\hline 5 & 0 & $0.29 \pm 0.09$ \\
\hline 10 & 0 & $0.53 \pm 0.18$ \\
\hline 15 & 0 & $0.65 \pm 0.15$ \\
\hline 15 & 0.5 & $0.83 \pm 0.05$ \\
\hline 15 & 1 & $0.90 \pm 0.08$ \\
\hline 15 & 5 & $1.06 \pm 0.09$ \\
\hline
\end{tabular}

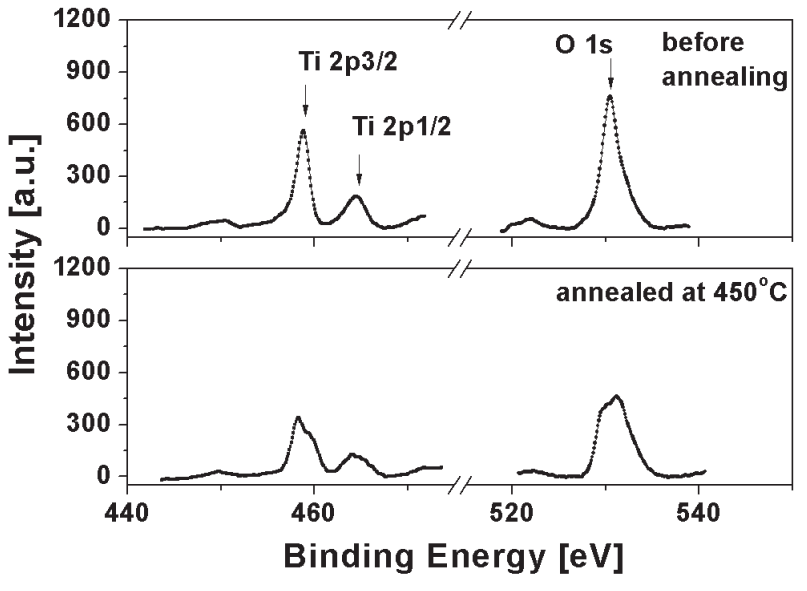

Fig. 3. XPS spectra of cathodically deposited $\mathrm{TiO}_{2}$ onto stainless steel.

Ti $2 \mathrm{p}_{3 / 2}(458.8 \mathrm{eV})$ and Ti $2 \mathrm{p}_{1 / 2}(464.5 \mathrm{eV})$ sublevels by spin-orbit coupling, and corresponds to the $\mathrm{Ti}^{4+}$ state. The peak at $530.4 \mathrm{eV}$ belongs to $\mathrm{O} 1 \mathrm{~s}$ in the O-Ti bond of $\mathrm{TiO}_{2}$. The peaks before annealing are sharp, whereas after annealing - as well for the Ti $2 p_{3 / 2}$ as O 1 s - the peaks exhibit a shoulder and are shifted slightly. This indicates that during annealment, foreign atoms were incorporated into the $\mathrm{TiO}_{2}$ lattice. Possible elements are $\mathrm{S}$ and $\mathrm{N}$ from the precursor and electrolyte, as well as $\mathrm{Fe}$ from the electrode. The spectra for $\mathrm{S} 2 \mathrm{p}_{3 / 2}$ and $\mathrm{N} 1 \mathrm{~s}$ are shown in Fig. 4 . The peaks of $\mathrm{N} 1 \mathrm{~s}$ and $\mathrm{S} 2 \mathrm{p}_{3 / 2}$ were of low intensity. The $\mathrm{N}$ 1s peak disappeared after annealing, indicating decomposition and desorption of the nitrate. The S $2 p_{3 / 2}$ peak appears at $169 \mathrm{eV}$, which can be ascribed to the presence of $\mathrm{S}^{6+}$ and $\mathrm{S}^{4+}$ species and not to $\mathrm{S}^{2-}$ species, which would exhibit binding energies between $160-163 \mathrm{eV}$ [32]. Thus, the $\mathrm{S} 2 \mathrm{p}_{3 / 2}$ peak indicates either the substitution of $\mathrm{Ti}^{4+}$ by $\mathrm{S}^{6+}$ and $\mathrm{S}^{4+}$ cations or the presence of $\mathrm{SO}_{4}^{2-}$ and $\mathrm{SO}_{3}^{2-}$ groups through bidentate bonds with $\mathrm{Ti}^{4+}$ [32]. The appearance of the shoulder of $\mathrm{O} 1 \mathrm{~s}$ peak can be associated with oxygen

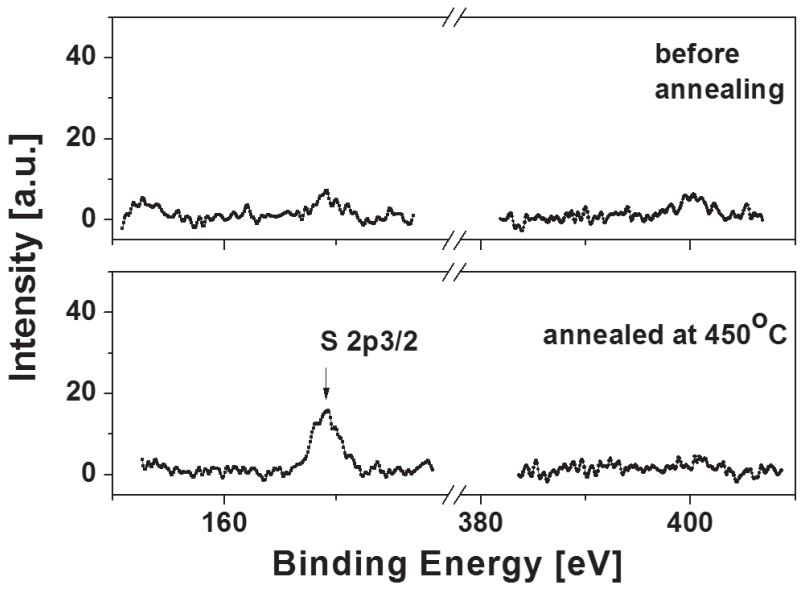

Fig. 4. XPS spectra of impurities from precursors of cathodic deposition. 


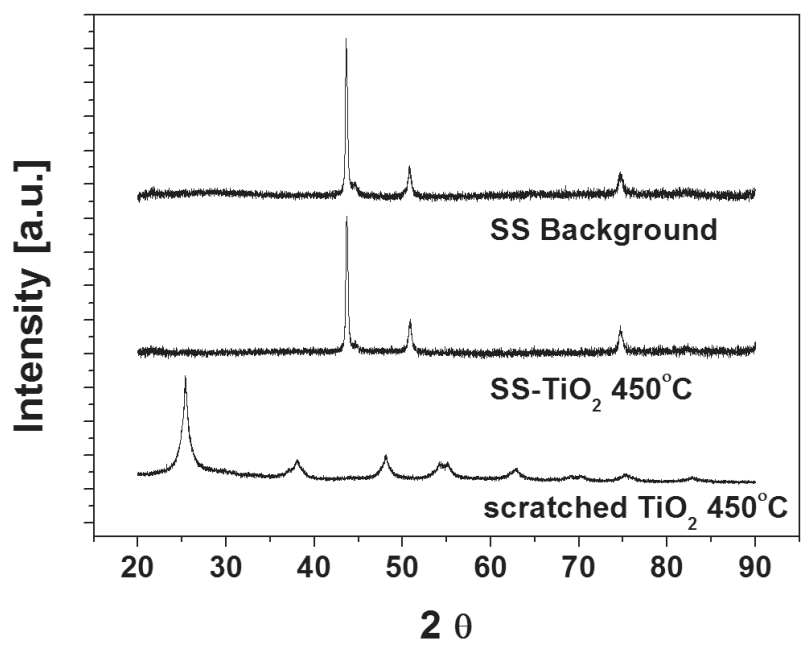

Fig. 5. XRD patterns of stainless steel electrode, electrode with $\mathrm{TiO}_{2}$ deposit and scratched off $\mathrm{TiO}_{2}$ deposit.

deficiency of the $\mathrm{TiO}_{2}$ or to the presence of iron oxides. It cannot be associated with oxygen in sulfate, since the binding energy is shifted to lower energy levels. The binding energy of oxygen in sulfate would be $531.4 \mathrm{eV}$ [33], whereas the biding energy of iron oxides is around $530 \mathrm{eV}$ and of oxygen deficiency is around $527 \mathrm{eV}$ [34]. The elemental mapping of electrode surface by EDX analysis revealed that the area not covered by $\mathrm{TiO}_{2}$ does not contain iron. Thus the observed shift of the $\mathrm{O}$ 1s peak rather results from the $\mathrm{TiO}_{2}$ layer scratching during sample preparation than from diffusion of iron ions into the $\mathrm{TiO}_{2}$ lattice during annealing. However, these impurities can influence photocatalytic activity and make the deposited film sensitive for visible light $[35,36]$.

When the attached deposits on the electrode were characterized by XRD, neither peaks for anatase nor for rutile phase were observed (see Fig. 5). Only peaks

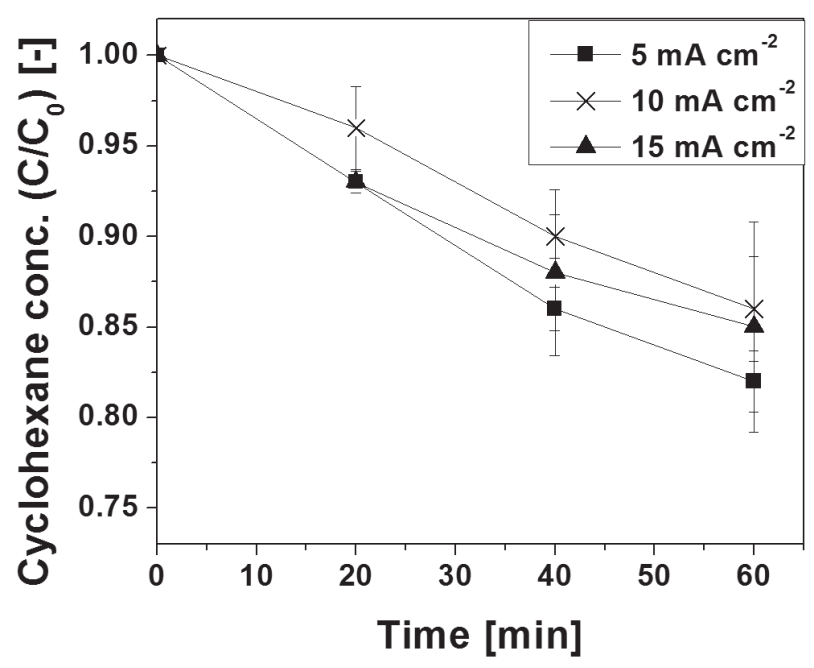

Fig. 6. Determination of photocatalytic activity of galvanostatically deposited $\mathrm{TiO}_{2}$ by cyclohexane decomposition.

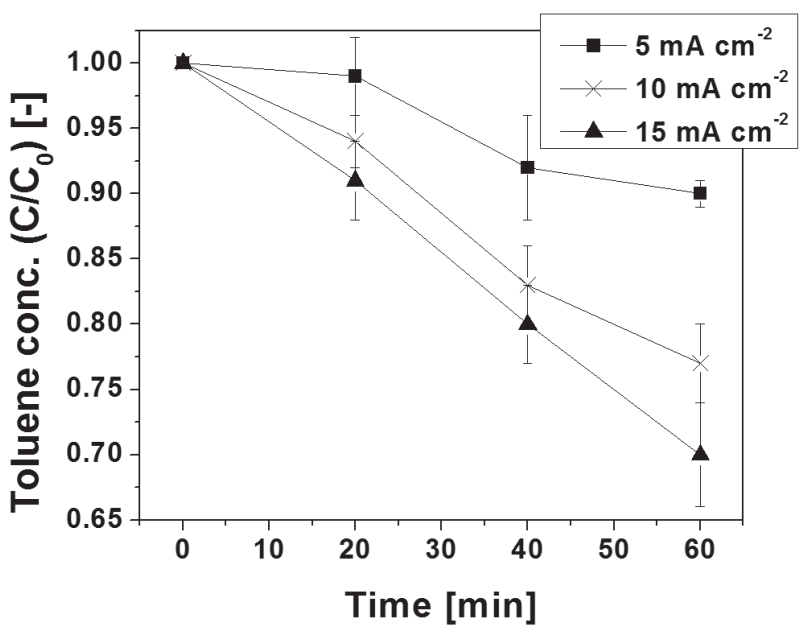

Fig. 7. Photocatalytic activity of galvanostatically deposited $\mathrm{TiO}_{2}$ determined by toluene decomposition.

of the stainless steel electrode can be distinguished. It was assumed that the formed $\mathrm{TiO}_{2}$ layer was too thin and for this reason the signal was too weak. For this reason, several electrodes were prepared by the same procedure and the deposited films were scratched off until a sufficient amount for XRD analysis was received. At $450^{\circ} \mathrm{C}$ a single tetragonal anatase- $\mathrm{TiO}_{2}$ phase was observed with characteristic peaks assigned to (101), (004), (200), (211), and (204) planes (from left to right). Thus, the results are consistent with previous results reported in the literature, where pure anatase was observed after annealing at $400^{\circ} \mathrm{C}[18,37]$.

The photocatalytic decomposition of cyclohexane by galvanostatically deposited $\mathrm{TiO}_{2}$ at different current densities is shown in Fig. 6. Around 15\% of cyclohexane were decomposed after one hour of irradiation. The amount of galvanostatically deposited photocatalyst had no influence on the photocatalytic decomposition of cyclohexane (compare with data in Table 1). In the case of the photocatalytic decomposition of toluene by galvanostatically deposited $\mathrm{TiO}_{2}$, the decomposition rate was slightly larger and the amount of deposited photocatalyst influenced the photocatalytic decomposition rate (Fig. 7). $30 \pm 4 \%$ of toluene were decomposed after one hour of irradiation by photocatalyst film deposited at $15 \mathrm{~mA} \mathrm{~cm}^{-2}$. With the increasing amount of photocatalyst the decomposition rate of toluene increased. The decomposition rates were compared to not-immobilized commercially available $\mathrm{TiO}_{2}$ photocatalyst P25 from Evonik (Fig. 8). Both cyclohexane and toluene were decomposed in less than $10 \mathrm{~min}$, when $0.7 \mathrm{mg}$ P25 (which equals $0.19 \mathrm{mg} \mathrm{cm}^{-2}$ ) was used. The given BET surface area of P25 is $50 \pm 15 \mathrm{~m}^{2} \mathrm{~g}^{-1}$. Assuming a flat $2 \mathrm{D}$ surface of cathodically deposited $\mathrm{TiO}_{2}$, the surface area was approximately $0.1 \mathrm{~m}^{2} \mathrm{~g}^{-1}$. Thus, the dissimilarities in the decomposition rate result from different photocatalytic active surface areas of cathodically deposited $\mathrm{TiO}_{2}$ and P25. 


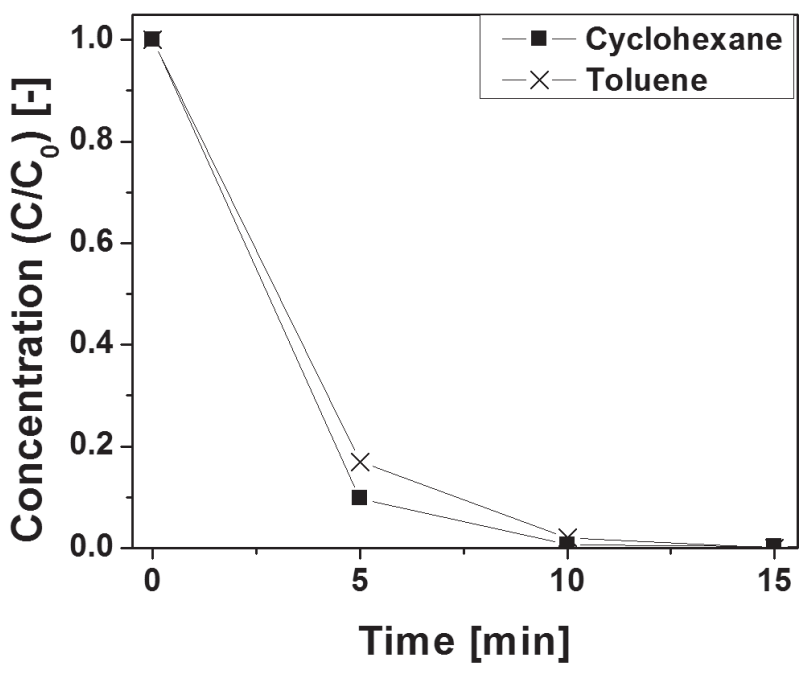

Fig. 8. Photocatalytic decomposition of cyclohexane and toluene by not immobilized $\mathrm{P} 25 \mathrm{TiO}_{2}$.

In order to increase the photocatalytic activity of cathodically deposited $\mathrm{TiO}_{2}$, the immobilization of P25 $\mathrm{TiO}_{2}$ nanoparticles by cathodic occlusion was investigated. Cathodically generated $\mathrm{TiO}_{2}$ should be a superior binding material for P25 immobilization. The results of photocatalytic decomposition of cyclohexane in the gas phase are shown in Fig. 9. The samples with $0.5 \mathrm{~g} \mathrm{dm}^{-3}$ and $1 \mathrm{~g} \mathrm{dm}^{-3}$ occluded P25 showed similar photocatalytic activity. The sample with $5 \mathrm{~g} \mathrm{dm}^{-3}$ occluded P25 showed the highest photocatalytic activity of all immobilized photocatalysts for decomposition of cyclohexane. 33\% of cyclohexane were decomposed within $60 \mathrm{~min}$ of irradiation. The rate of toluene decomposition was even more enhanced than in comparison to cyclohexane. After 15, 5, and 4 min, toluene was decomposed by samples with P25 in amounts of $0.5,1$, and $5 \mathrm{~g} \mathrm{dm}^{-3}$ in the deposition bath, respectively (Fig. 10).

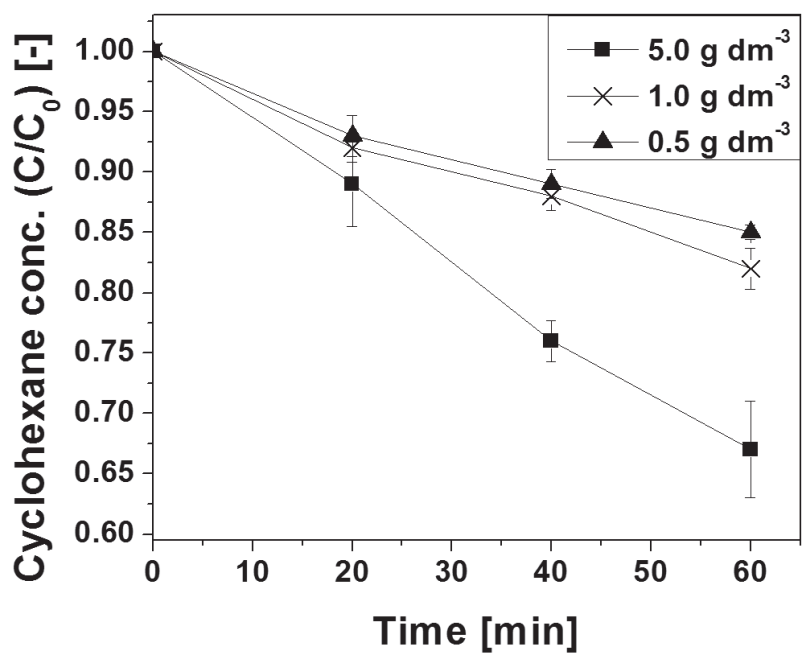

Fig. 9. Photocatalytic activity of $\mathrm{P} 25 \mathrm{TiO}_{2}$ immobilized particles as determined by cyclohexane decomposition.

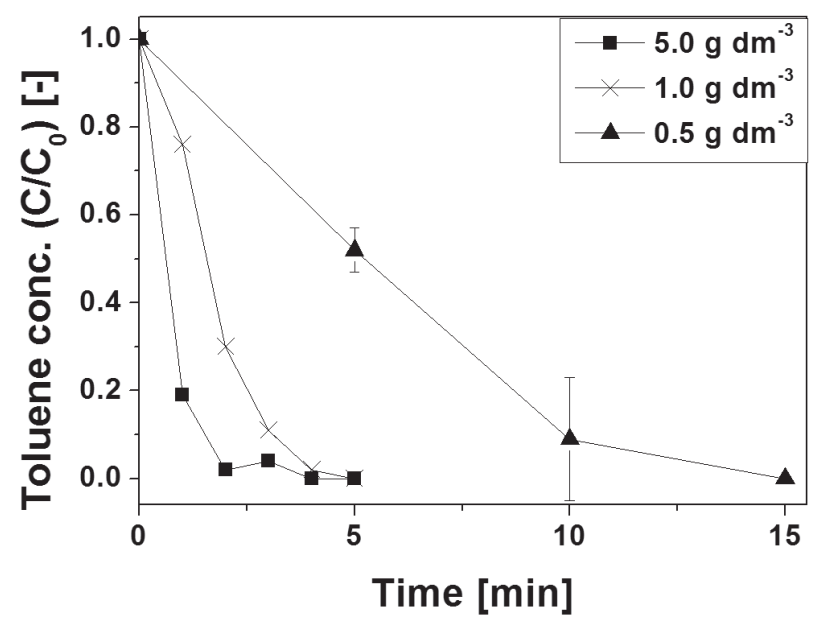

Fig. 10. Photocatalytic activity of $\mathrm{P} 25 \mathrm{TiO}_{2}$ immobilized particles as determined by toluene decomposition.

Fig. 11 shows typically recorded cyclic voltammograms at dark and UV irradiation. In the dark, no significant current densities were observed for the forward scan, which was expected for n-type photocatalysts [37]. Approaching the potential of $0.8 \mathrm{~V}$ in the dark, the current density increases, which can be caused by depassivation of the stainless steel [38]. Under UV irradiation, photocurrent was observed for increasing potential, since the electronhole recombination was suppressed. With an increasing amount of photocatalyst mass per area, the photocurrent density increased and was the largest (1.51E-06 $\mathrm{A} \mathrm{cm}^{-2}$ ) for the sample with $5 \mathrm{~g} \mathrm{dm}^{-3}$ occluded P25 (see Table 2). For the samples without occluded P25 particles, it was assumed that the deposited photocatalyst mass per area was directly proportional to the thickness of deposited film. Assuming that the deposited film was anatase with a density of $3.89 \mathrm{~g} \mathrm{~cm}^{-3}$ [39], the thickness of galvanostatically deposited films at $5 \mathrm{~mA} \mathrm{~cm}^{-2}$ and $15 \mathrm{~mA} \mathrm{~cm}^{-2}$ increased from $0.8 \mu \mathrm{m}$ to up $4.1 \mu \mathrm{m}$, respectively. Since UV light of $365 \mathrm{~nm}$ can

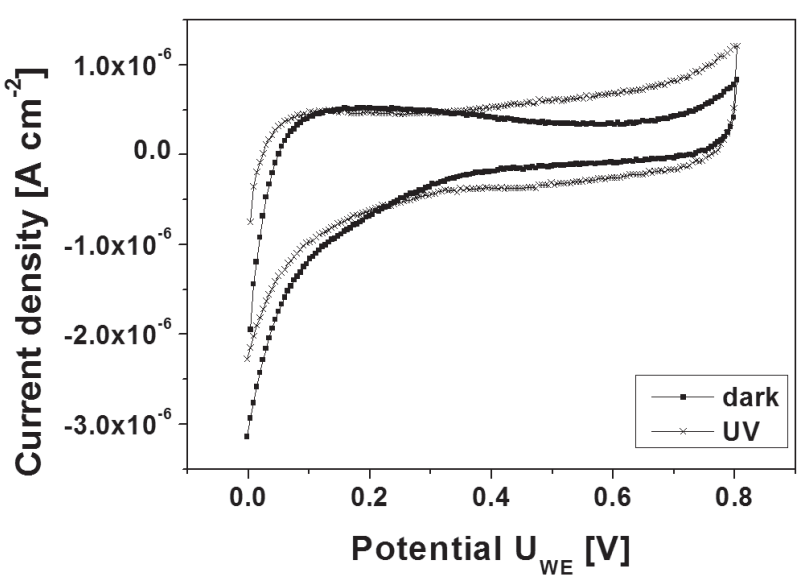

Fig. 11. Cyclic voltammograms obtained for photocatalyst deposited at $15 \mathrm{~mA} \mathrm{~cm}^{-2}$ in dark and under UV irradiation. 
Table 2. Photocurrent densities determined at $0.8 \mathrm{~V}$ depending on photocatalyst amount

\begin{tabular}{|c|c|c|}
\hline $\begin{array}{c}\text { Sample } \\
(-)\end{array}$ & $\begin{array}{c}\text { Net photocurrent density } \\
\left(\mathrm{A} \mathrm{cm}^{-2}\right)\end{array}$ & $\begin{array}{c}\text { Mass/Area } \\
\left(\mathrm{mg} \mathrm{cm}^{-2}\right)\end{array}$ \\
\hline $5 \mathrm{~mA} \mathrm{~cm}^{-2}$ & $8.19 \mathrm{E}-08$ & 0.16 \\
\hline $10 \mathrm{~mA} \mathrm{~cm}^{-2}$ & $3.47 \mathrm{E}-07$ & 0.32 \\
\hline $15 \mathrm{~mA} \mathrm{~cm}^{-2}$ & $4.10 \mathrm{E}-07$ & 0.56 \\
\hline $0.5 \mathrm{~g} \mathrm{dm}^{-3}$ & $1.32 \mathrm{E}-06$ & 0.77 \\
\hline $1 \mathrm{~g} \mathrm{dm}^{-3}$ & $1.36 \mathrm{E}-06$ & 0.97 \\
\hline $5 \mathrm{~g} \mathrm{dm}^{-3}$ & $1.51 \mathrm{E}-06$ & 1.10 \\
\hline
\end{tabular}

penetrate $\mathrm{TiO}_{2}$ layers of up to $1.4 \mu \mathrm{m}$ [40], more incident UV light was absorbed with increasing film thickness, which explains the increase in photocurrent density. The films with occluded P25 particles had a thickness of around $7 \mu \mathrm{m}$. The increase of the photocurrent density of the samples with occluded P25 particles by a factor of around four was caused by the increase of real electrode area, since a change from a 2D surface to a 3D structure occurred (Fig. 2). However, the rise of photocurrent density with an increasing amount of occluded P25 was weaker than in comparison to samples with flat photocatalyst film, which means that the total absorption of incident UV light was approached.

\section{Conclusions}

The immobilization of photocatalytic materials is indispensable, if they shall be applied in a large scale. Until today only a small number of papers has discussed the photocatalytic activity of cathodically deposited $\mathrm{TiO}_{2}$ films on frequently used construction materials. In the present paper $\mathrm{TiO}_{2}$ films were cathodically deposited onto stainless steel. Furthermore, P25 $\mathrm{TiO}_{2}$ particles were occluded in the cathodical film by which also the photocatalytic properties of the film were modified. The deposition was confirmed by SEM and XPS measurements. The cathodically synthesized $\mathrm{TiO}_{2}$ formed non-continuous cracked films, while the occlusion of P25 led to the formation of 3D structures. All prepared films showed photocatalytic activity, which was determined by the decomposition of the common indoor-air pollutants cyclohexane and toluene in the gas phase. Additionally, the photocurrent density of the deposited films was measured. The occlusion of P25 particles in the $\mathrm{TiO}_{2}$ film enhanced photoactivity. The photocatalytic activity and the photocurrent density reached maximum for the photocatalytic films prepared with $5 \mathrm{~g} \mathrm{dm}^{-3}$ of P25 in the deposition bath. Thus, the electrochemical occlusion of photocatalyst particles into oxide films is a promising method to immobilize photocatalyst particles. This approach gives us the possibility to design and produce immobilized photocatalytic films with desired properties, since various kinds of photocatalytic nanoparticles can be occluded. Furthermore, different kinds of cathodic films or mixed oxide films can be used, whereas more research would be needed.

\section{Acknowledgements}

This research was financed by the Polish National Center of Science (contract No. 2011/03/N/ST5/04394).

\section{Conflict of Interest}

The authors declare no conflict of interest.

\section{References}

1. TARANTO J., FROCHOT D., PICHAT P. Photocatalytic air purification: Comparative efficacy and pressure drop of a $\mathrm{TiO}_{2}$-coated thin mesh and a honeycomb monolith at high air velocities using a $0.4 \mathrm{~m}^{3}$ close-loop reactor. Sep. Purif. Technol., 67 (2), 187, 2009.

2. HÄNEL A., MOREŃ P., ZALESKA A., HUPKA J. Photocatalytic activity of $\mathrm{TiO}_{2}$ immobilized on glass beads. Physicochem. Probl. Miner. Process., 45, 49, 2010.

3. ZALESKA A., HÄNEL A., NISCHK M. Photocatalytic air purification. Recent Paten. Eng., 4 (3), 200, 2010.

4. ZMUDZIŃSKI W. Removal of o-Cresol from Water by Adsorption/Photocatalysis. Pol. J. Environ. Stud., 19 (6), 1353, 2010.

5. POZZO R.L., BALTANAS M.A., and CASSANO A.E. Supported titanium oxide as photocatalyst in water decontamination: State of the art. Catal. Today, 39 (3), 219, 1997.

6. ZHANG Y., XIONG X., HAN Y., ZHANG X., SHEN F., DENG S., XIAO H., YANG X., YANG G., and PENG H. Photoelectrocatalytic degradation of recalcitrant organic pollutants using $\mathrm{TiO}_{2}$ film electrodes: An overview. Chemosphere, 88 (2), 145, 2012.

7. LEE W., PARK S.-J. Porous anodic aluminum oxide: anodization and templated synthesis of functional nanostructures. Chem. Rev. (Washington, DC, U. S.), 114 (15), 7487, 2014.

8. ZWILLING V., AUCOUTURIER M., DARQUECERETTI E. Anodic oxidation of titanium and TA6V alloy in chromic media. An electrochemical approach. Electrochim. Acta, 45 (6), 921, 1999.

9. JUN Y., PARK J.H., KANG M.G. The preparation of highly ordered $\mathrm{TiO}_{2}$ nanotube arrays by an anodization method and their applications. Chem. Commun., 48 (52), 6456, 2012

10. RANI S., ROY S.C., PAULOSE M., VARGHESE O.K., MOR G.K., KIM S., YORIYA S., LATEMPA T.J., GRIMES C. Synthesis and applications of electrochemically self-assembled titania nanotube arrays. Phys. Chem. Chem. Phys., 12 (12), 2780, 2010.

11. FENG Z.-S., CHEN J.-J., ZHANG C., ZHAO N., LIANG Z. Formation of $\mathrm{Al}_{2} \mathrm{O}_{3}-\mathrm{TiO}_{2}$ composite oxide films on aluminum foil by cathodic electrodeposition and anodizing. Ceram. Int., 38 (3), 2501, 2012.

12. ERTEKIN Z., TAMER U., PEKMEZ K. Cathodic electrochemical deposition of Magnéli phases $\mathrm{Ti}_{\mathrm{n}} \mathrm{O}_{2 \mathrm{n}-1}$ thin 
films at different temperatures in acetonitrile solution. Electrochim. Acta, 163, 77, 2015.

13. KAVAN L. Nanomaterials based on carbon and Ti (IV) oxides: Some aspects of their electrochemistry. Int. J. Nanotech., 9 (8-9), 652, 2012.

14. CHIGANE M., SHINAGAWA T. Preparation of Thick Titanium Dioxide Films by Repeated ElectrolysisCalcination for Dye-Sensitized Solar Cells. J. Electrochem. Soc., 161 (3), E40, 2014.

15. WESSELS K., WARK M., OEKERMANN T. Efficiency improvement of dye-sensitized solar cells based on electrodeposited $\mathrm{TiO}_{2}$ films by low temperature posttreatment. Electrochim. Acta, 55 (22), 6352, 2010.

16. LIU L., MANDLER D., Sol-Gel Coatings by Electrochemical Deposition, in The Sol-Gel Handbook: Synthesis, Characterization and Applications; Levy D. and Zayat M., Eds., John Wiley \& Sons: Weinheim, Volume 2, pp. 373, 2015.

17. PIFFERI V., SPADAVECCHIA F., CAPPELLETTI G., PAOLI E.A., BIANCHI C.L., FALCIOLA L. Electrodeposited nano-titania films for photocatalytic $\mathrm{Cr}(\mathrm{VI})$ reduction. Catal. Today, 209, 8, 2013.

18. CHENTHAMARAKSHAN C.R., DE TACCONI N.R., RAJESHWAR K., SHIRATSUCHI R. Immobilizing semiconductor particles by occlusion electrosynthesis in an oxide film matrix: The titania model case. Electrochem. Commun., 4 (11), 871, 2002.

19. GEORGIEVA J. $\mathrm{TiO}_{2} / \mathrm{WO}_{3}$ photoanodes with enhanced photocatalytic activity for air treatment in a polymer electrolyte cell. J. Solid State Electrochem., 16 (3), 1111, 2011.

20. GEORGIEVA J., SOTIROPOULOS S., ARMYANOV S., PHILIPPIDIS N., POULIOS I. Photoelectrocatalytic activity of bi-layer $\mathrm{TiO}_{2} / \mathrm{WO}_{3}$ coatings for the degradation of 4-chlorophenol: effect of morphology and catalyst loading. J. Appl. Electrochem., 41 (2), 173, 2011.

21. ISHIZAKI H., ITO S. Electrochemical Fabrication of Titanium Oxide Film from an Aqueous Solution Containing Titanium Ion and Hydroxylamine. ECS Trans., 41 (4), 111, 2011.

22. SAYAHI H., MOHSENZADEH F., HAMADANIAN M. Cost-effective fabrication of perdurable electrodeposited $\mathrm{TiO}_{2}$ nano-layers on stainless steel electrodes applicable to photocatalytic degradation of methylene blue. Res. Chem. Intermed., 1, 2017.

23. TRUONG Q.D., DIEN L.X., VO D.-V.N., LE T.S. Controlled synthesis of titania using water-soluble titanium complexes: A review. J. Solid State Chem., 251, 143, 2017.

24. KAKIHANA M., KOBAYASHI M., TOMITA K., PETRYKIN V. Application of Water-Soluble Titanium Complexes as Precursors for Synthesis of TitaniumContaining Oxides via Aqueous Solution Processes. Bull. Chem. Soc. Jpn., 83 (11), 1285, 2010.

25. ZHITOMIRSKY I., GAL-OR L., KOHN A., HENNICKE H.W. Electrodeposition of ceramic films from non-aqueous and mixed solutions. J. Mater. Sci., 30 (20), 5307, 1995.

26. MÜHLEBACH J., MÜLLER K., SCHWARZENBACH G. Peroxo complexes of titanium. Inorg. Chem., 9, 2381, 1970.
27. BARD A.J., FAULKNER L.R. Electrochemical Methods - Fundamentals and Applications, $2^{\text {nd }}$ ed; John Wiley \& Sons Inc.: New York, USA, pp. 809, 2001.

28. THERESE G.H.A., KAMATH P.V. Electrochemical synthesis of metal oxides and hydroxides. Chem. Mater., $12(5), 1195,2000$

29. HÄNEL A. Evaluation of cathode materials for the electrochemical photocatalyst deposition. PhD Interdiscipl. J., 1, 175, 2015.

30. NISCHK M., MAZIERSKI P., GAZDA M., ZALESKA A. Ordered $\mathrm{TiO}_{2}$ nanotubes: The effect of preparation parameters on the photocatalytic activity in air purification process. Appl. Catal., B, 144, 674, 2014.

31. MIODUSKA J., ZIELIŃSKA-JUREK A., HUPKA J. Photocatalytical degradation of toluene and cyclohexane using LED illumination. Pol. J. Environ. Stud., 26 (3), 1159, 2017.

32. HAN C., PELAEZ M., LIKODIMOS V., KONTOS A.G., FALARAS P., O'SHEA K., DIONYSIOU D.D. Innovative visible light-activated sulfur doped $\mathrm{TiO}_{2}$ films for water treatment. Appl. Catal., B, 107 (1-2), 77, 2011.

33. ARMAN S.Y., OMIDVAR H., TABAIAN S.H., SAJJADNEJAD M., FOULADVAND S., AFSHAR S. Evaluation of nanostructured S-doped $\mathrm{TiO}_{2}$ thin films and their photoelectrochemical application as photoanode for corrosion protection of 304 stainless steel. Surf. Coat. Technol., 251 (25), 162, 2014.

34. BARR T.L. An ESCA study of the termination of the passivation of elemental metals. J. Phys. Chem., 82 (16), 1801, 1978.

35. YU Q.L. BROUWERS H.J.H. Indoor air purification using heterogeneous photocatalytic oxidation part I: Experimental study. Appl. Catal., B, 92, 454, 2009.

36. WANG Y., HUANG Y., HO W., ZHANG L., ZOU Z., LEE S. Biomolecule-controlled hydrothermal synthesis of CNS-tridoped $\mathrm{TiO}_{2}$ nanocrystalline photocatalysts for $\mathrm{NO}$ removal under simulated solar light irradiation. J. Hazard. Mater., 169 (1-3), 77, 2009.

37. GEORGIEVA J., ARMYANOV S., VALOVA E., POULIOS I., SOTIROPOULOS S. Preparation and photoelectrochemical characterisation of electrosynthesised titanium dioxide deposits on stainless steel substrates. Electrochim. Acta, 51 (10), 2076, 2006.

38. DROGOWSKA M., MÈNARD H., BROSSARD L. Electrooxidation of Stainless Steel AISI 304 in Carbonate Aqueous Solution at pH 8. J. Appl. Electrochem., 26 (2), 217, 1996.

39. YANG Z., CHOI D., KERISIT S., ROSSO K.M., WANG D., ZHANG J., GRAFF G., LIU J. Nanostructures and lithium electrochemical reactivity of lithium titanites and titanium oxides: A review. J. Power Sources, 192 (2), 588, 2009.

40. YANG L., LIU Z., SHI J., HU H., SHANGGUAN W. Design consideration of photocatalytic oxidation reactors using $\mathrm{eTiO}_{2}$-coated foam nickels for degrading indoor gaseous formaldehyde. Catal. Today, 126 (3-4), 359, 2007. 